\title{
From the Desk of the Residency Program Director
}

\author{
Gretchen Diemer, MD, FACP \\ Thomas Jefferson University, gretchen.diemer@jefferson.edu
}

Follow this and additional works at: https://jdc.jefferson.edu/tmf

Part of the Medicine and Health Sciences Commons

Let us know how access to this document benefits you

\author{
Recommended Citation \\ Diemer, MD, FACP, Gretchen (2015) "From the Desk of the Residency Program Director," The Medicine \\ Forum: Vol. 16 , Article 1. \\ DOI: https://doi.org/10.29046/TMF.016.1.001 \\ Available at: https://jdc.jefferson.edu/tmf/vol16/iss1/1
}

This Article is brought to you for free and open access by the Jefferson Digital Commons. The Jefferson Digital Commons is a service of Thomas Jefferson University's Center for Teaching and Learning (CTL). The Commons is a showcase for Jefferson books and journals, peer-reviewed scholarly publications, unique historical collections from the University archives, and teaching tools. The Jefferson Digital Commons allows researchers and interested readers anywhere in the world to learn about and keep up to date with Jefferson scholarship. This article has been accepted for inclusion in The Medicine Forum by an authorized administrator of the Jefferson Digital Commons. For more information, please contact: JeffersonDigitalCommons@jefferson.edu. 


\section{FROM THE DESK OF THE RESIDENCY PROGRAM DIRECTOR}

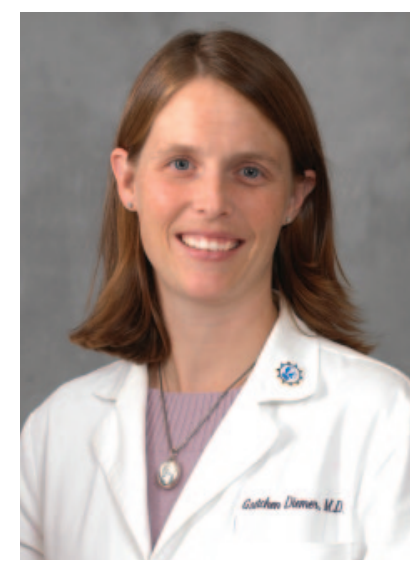

\section{Welcome to the Forum!}

It is bittersweet to write my final Message from the Program Director for the Forum. This publication is one example of the passion, talent, creativity and scientific inquisitiveness of our Jefferson residents. As a completely resident run journal, what follows in this journal helps prove to me that the future of medicine is in good hands.

In my time as program director, we have seen many changes in the healthcare landscape, both nationally and locally at Jefferson. We have launched the Milestone evaluations in the Next Accreditation System for the ACGME and are embarking on major curricular reform at the UME level to better align training as a continuum. We are having real and meaningful conversations about quality, safety and value and thinking critically about those aspects of our care of patients. Wellness is a concept that no longer only conjures yoga and crystals, but is taking shape in our curriculum to train doctors who can cope with the difficult situations they watch their patients endure every day and the stressors that being a physician piles onto their lives. The new EMR is increasingly seeming like a reality and more of our patients are insured and taking ownership of their health.

As I prepare for the next step in my career, I marvel at what our residents are capable of and it makes my heart burst with pride when I watch them in action! I will always strive to be a meaningful part of the education of our residents and hope to continue to make Jefferson an ever stronger place to learn to practice medicine. I leave you in good hands and you will all remain in a special place in my heart for all we've been through together!

Never stop trying to be the best at what you do!

All the best,

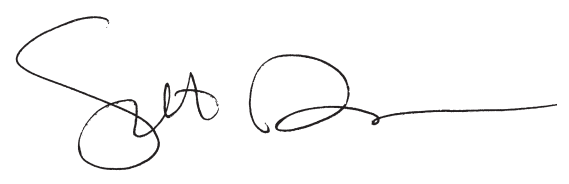

Gretchen Diemer, MD, FACP

Associate Professor of Medicine

Program Director Internal Medicine

Associate Dean for GME and Affiliations 